\title{
Effect of Clinoptilolite on Humoral Immunity and Biochemical Parameters in Calves Vaccinated with Foot and Mouth Disease Vaccine
}

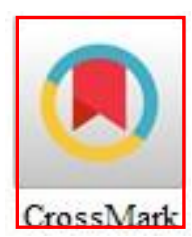

\author{
Nour Elhoda M Tamim ${ }^{*}$, Dawlat A Salama ${ }^{2}$, Hany AM Srour ${ }^{2}$, Ehab E Ibrahim ${ }^{1}$ \\ 1- Foot and Mouth Diseases Department, Veterinary Serum and Vaccine Research Institute, Abbasia, \\ Agriculture research center (ARC), Cairo, Egypt \\ 2- Biochemistry Department, Faculty of Agriculture, Ain Shams University, P.O. Box 68, Hadyek Shoubra \\ 11241, Cairo, Egypt \\ * Corresponding author: Nour.Tamim@agr.asu.edu.eg
}

DOI: 10.21608/ajs.2021.87950.1403

Received 9 August, 2021 ; Accepted 21 November, 2021

\section{Keywords:}

Adjuvant, Biochemical parameters, Calves, FMD, Humoral immunity, Vaccine

\section{Introduction}

Foot and mouth disease (FMD) was recognized as a highly contagious viral disease affecting various species of cloven-hoofed animals (Sobhy et al 2018). The FMD virus (FMDV) is an aphthovirus that belongs to the Picornaviridae family (Salam et al 2014). FMDV can be transmitted immediately from infected to uninfected animals in the same place or indirectly spread among susceptible animals by contaminated air or through people. One of the countries that have spread the FMD virus is Egypt and it has taken many outbreaks had occurred since 1950 and onwards. The FMDV serotype $(\mathrm{O})$ was the most epidemic until serotype "A" appeared in 2006. Locally, several outbreaks of FMD have recorded among calves and buffaloes and was confirmed in mid-February 2006 that it is serotype "A" (OIE 2006). After that, during the beginning of 2012, the OIE recorded that there were cases numbers of FMD serotype SAT2 infectious in Egypt. In addition to this, endemic serotypes (A and O) still spread in the country (Lockhart et al 2012).

Vaccination is the first line on a large scale to control disease. Vaccines provide the most defense and cost-efficient means to prevent this infectious disease. 
One of the most important steps in vaccine preparation is the selection of a suitable adjuvant which plays a main role in the elevation of the vaccine efficacy (Ibrahim 2002). Most commercially available FMD vaccines are consider inactivated whole-virus preparations containing Montanide ISA 206 oil emulsion as an adjuvant to improve their efficacy and to elevation of immune response in vaccinated calves (Robinson and Christley 2007). The blood immune cell parameters showed a positive immunological response due to their activation by the vaccine antigens (Chukwuedo et al 2016). Some studies showed that the immunization of inactivated FMD vaccine with Montanide 206 oil was capable of could induce $80 \%$ to $100 \%$ protection (Khalifa et al 2017). So, significant steps have been made to improve the quality of these vaccines by using other adjuvants (Brown and Bevins 2019).

Clinoptilolite is a natural clay that contains aluminum silicates that have formed from oxygen, aluminum, and silicon. $\mathrm{SiO}_{4}$ and $\mathrm{AlO}_{4}$ tetrahedral are the smallest units that give a specific shape to the molecule. Clinoptilolite has special and outstanding physical and chemical properties. These characteristics make them very useful in various applications, including agriculture, animal feeding, veterinary medicine, and agronomy. Newly, the application of clinoptilolite has been notarized in human medicine and pharmaceuticals (Kraljević Pavelić et al 2018). Clinoptilolite has a high affinity toward cations and plays the main role in regulating the immune system, so may prove useful as an adjuvant to the standard therapy (Yao et al 2016).

This work was designed to evaluate the replacement of the adjuvant of commercial vaccine, Montanid ISA 206 oil, with clinoptilolite by $50 \%$ or $100 \%$ on the immunological changes by determination of serum neutralization test (SNT). Also, the determination of the effect of replacement of Montanid, with clinoptilolite as an adjuvant of FMD vaccine on blood biochemical parameters in calves, was highlighted.

\section{Materials and Methods}

\subsection{Animals}

Ten -months-old calves "Egyptian Balady calves" ( $\mathrm{n}=12)$, were used in our study, and tested negative for FMD serotype antibodies by serum neutralization test (SNT). The experiment was carried out in the Veterinary Serum and Vac- cine Research Institute (VSVRI). The use of protocols and calves were confirmed by the Animal Care and Use Committee of VSVRI, Egypt.

\subsection{FMD viruses}

A locally isolated FMD virus strains (O PanAsia-2, A/Iran/05, and SAT2/EGY/2012) were provided from VSVRI, Abbassia, Egypt, and used in vaccine preparation and serum neutralization test (SNT). The viral serotypes were stored at $-70^{\circ} \mathrm{C}$. The $\mathrm{BHK}-21$ cell line was used to propagate the three serotype seed viruses and the harvested viruses were inactivated chemically by binary ethylene imine (BEI) according to Ismail et al (2013).

\subsection{Preparation of vaccines}

Three vaccines were prepared by using two types of adjuvants: Montanid ISA 206 and clinoptilolite. The antigen: adjuvant ratios were agreed according to the procedure described by Barnett et al (1996). Montanid ISA 206 is a mineral oil-based adjuvant form a water/oil/water emulsion or a double emulsion (continuous aqueous phase emulsion inside which droplets of oil contain a second aqueous phase) without the need for surfactant. It was obtained from Seppic, Paris, France.

Clinoptilolite is the fine powder of natural clay was obtained by Micronisiertes Klinoptilolith Hochwertigs Naturminera, Germany. Adding 1 $\mu \mathrm{g} /$ dose of clinoptilolite to FMD inactivated virus mixture was according to Mansouri et al (2013).

\subsection{Safety and sterility of the prepared FMD vac- cines}

A safety test was conducted by OIE (2006) to confirm the absence of any abnormal local or systemic adverse reactions post-vaccination. A sterility test was conducted to confirm the freedom of the prepared vaccines from any contaminations.

\subsection{Experimental design of animal groups}

In our study, twelve calves were split into four groups, each group contains three calves. The first group was vaccinated intramuscularly with FMD Montanide ISA 206 oil (ISA 206), the second group was vaccinated with FMD vaccine containing $50 \%$ Montanide ISA $206 \mathrm{oil} / \mathrm{dose}$ with $1.0 \mu \mathrm{g} / \mathrm{dose}$ of clinoptilolite (w/ $1 / 2 \mathrm{w}$ oil/ $1.0 \mu \mathrm{g} /$ dose clinoptilolite) (ISA 206+CLINP), while the Third group was vaccinated with trivalent FMD vaccine by replacing the 
$100 \%$ of Montanide ISA 206 oil by $1 \mu \mathrm{g} /$ dose of clinoptilolite (CLINP) and the fourth group was unvaccinated used as control. The humoral response of calves was estimated by serum neutralization test (SNT). Evaluation of biochemical parameters involves serum urea and creatinine concentrations, serum aspartate transaminase (AST) EC 2.6.1.1, alanine transaminase (ALT) EC 2.6.1.2 activities, total protein, albumin, globulins, and albumin/globulin ratio.

\subsection{Evaluation of humoral response}

Serum samples were collected from the vaccinated groups and unvaccinated calves weekly for one month then every 2 weeks until 40 weeks for evaluation of antibody titers against FMD virus strains $(\mathrm{O} / \mathrm{pan} / \mathrm{Asia} 2, \mathrm{~A} / \mathrm{Iran} / 05$ and SAT2/EGY/2012) using the neutralization assay as described previously (OIE 2012) and The SNT was calculated according to Reed and Muench (1938).

\subsection{Biochemical analysis}

Serum samples were taken at time zero, after that through $1,2,3,4,6,8$, and 10 weeks for biochemical analysis. Biochemical parameters, serum urea concentration was determined using the method of Artiss and Entwistle (1981) while creatinine concentration was measured according to (Bowers and Wong 1980). While the method for determination of ALT and AST activities are optimized in according to Henry (1964).

Serum total protein was determined using the method of Yatzidis (1987), and albumin was measured according to Doumas and Biggs (1976). Concentration of serum globulins was calculated by subtracting serum albumin concentration from total protein concentration.

Our parameters were performed by spectrophotometric method by using commercially available test kits provided from Biomed Diagnostics Company (Germany) except creatinine kit that was supplied from Spectrum Diagnostics Company (Germany).

\subsection{Statistical analysis}

The obtained data were analyzed using the Graph Pad Prism 8 program by using two-way ANOVA to conclude the statistical significance of differences among groups. The data presented as means of individuals \pm standard deviation (SD).

\section{Results and Discussion}

\subsection{Titration of FMDV harvests after inoculation on BHK-21 cells}

The FMD virus harvests were titrated in tissue culture plates using Baby Hamster Kidney (BHK-21) cells to detect the infectivity titer symbolized as $\log _{10}$ $\mathrm{TCID}_{50} / \mathrm{ml}$. They were $10^{8.5}, 10^{8}$, and $10^{7.6}$ respectively with FMDV serotype (O/pan Asia2, A/Iran 05 and SAT2/EGY/2012).

\subsection{Immunological responses of FMD vaccines}

FMD vaccine enhances the humoral immune response in the vaccinated calves, and there was a good engagement between antibody levels and protection against live virus challenge for the same strain of studied virus from which the vaccine was produced (Brown 1999). In general, it is recognized that a higher concentration of immunoglobulins gives more protection against FMD.

The immune response to the first vaccination depends on the antigen's dose and additive adjuvants which increase antibody production and produce a higher level of immune response (Park 2013). Therefore, the vaccines that have recently been used worldwide improve immunity and secure long-lasting antibodies by using the oil for adjuvants. On the other hand, the oil-adjuvant vaccine significantly increases humoral immunity and has superior antibody formation (Doel 1996). Humoral immunity was evaluated by SNT.

After vaccination against the FMD virus, the antibody titers of calves were evaluated using the SNT (McCullough et al 1992). Table 1 shows the means of serum neutralizing test (SNT) in three groups postvaccination. Calves vaccinated with inactivated FMD (ISA 206) vaccine recorded protective antibody titer at $2^{\text {nd }}$ WPV $\left(1.55^{\mathrm{b}} \pm 0.09\right)$, for three serotypes $(\mathrm{O}, A$, SAT2) while, animals vaccinated with inactivated FMD (ISA 206 + CLINP) vaccine recorded protective antibody titer at $1^{\text {st }}$ week post vaccination (WPV) $\left(1.70^{\mathrm{c}} \pm 0.09\right)$ for serotype $\mathrm{O},\left(1.75^{\mathrm{b}} \pm 0.09\right)$ for serotypes A and SAT2. Also calves vaccinated with inactivated FMD (CLINP) vaccine recorded protective antibody titer at $1^{\text {st }}$ WPV $\left(1.55^{\mathrm{cb}} \pm 0.09\right)$ for serotypes $\mathrm{O}$ and SAT2, $\left(1.6^{\mathrm{b}} \pm 0.09\right)$ for serotype A. The protective antibody titers of the vaccinated groups were increased gradually until peaking at the $12^{\text {th }} \mathrm{WPV}\left(2.97^{\mathrm{c}}\right.$ $\pm 0.03)$ for serotype $\mathrm{O},\left(3.05^{\mathrm{c}} \pm 0.03\right)$ for serotypes A and SAT2 with (ISA 206) vaccine. Also (ISA $206+$ CLINP) vaccine reached peak at $12^{\text {nd }}$ WPV $\left(3.25^{\mathrm{c}} \pm 0.09\right)$ for serotypes A and SAT2, $\left(3.1^{\mathrm{c}} \pm 0.03\right)$ 
for serotype O. While the group vaccinated with (CLINP) vaccine reached peak at $10^{\text {th }} \mathrm{WPV}\left(2.9^{\mathrm{b}} \pm\right.$ $0.09)$ for serotypes A and SAT2, $\left(2.6^{\mathrm{b}} \pm 0.09\right)$ for serotype $\mathrm{O}$ and failed to protect animals for a long time whereas the antibody titer decreased below by $26^{\text {th }}$ week $\left(1.55^{\mathrm{b}} \pm 0.09\right)$ for three serotypes, till the end of the experiment. The protective antibody titer slightly decreased in (ISA 206+CLINP) compared to (ISA 206) by the end of our study at the $38^{\text {th }}, 32^{\text {nd }}$ WPV respectively. This can be interpreted according to Emmer et al (2014) who found that the antigen-activated T-lymphocytes induce the humoral and cellular immune response. Also, lymphocytes can be enhanced by silicates, which are also considered as foreign bodies, they are already conduct for different silicate materials in lab conditions and this mechanism may be understood as the immunomodulatory activity of clinoptilolite (Aikoh et al 1998). Our results show that the incorporation of the (ISA 206+CLINP) inactivated FMD vaccine stimulates the protective immune response in calves. Additionally, using clinoptilolite as an adjuvant in vaccines can enhance the humoral immune response.

Fig 1 shows the period of protection for three groups post-vaccination for FMD serotypes. Calves vaccinated with inactivated FMD (ISA 206+CLINP) vaccine recorded higher and longer protection period reached to $38^{\text {th }}$ WPV than the other groups for three serotypes. This may be attributed to the composition of clinoptilolite as basic material containing silicates which in particular stimulates the immune response (Jurki'c et al 2013).

\subsection{Serum biochemical analysis}

This study also shows the effect of the FMD vaccine with different adjuvants on biochemical parameters. Detection of variations in enzyme concentrations presented in the serum can spot tissue and/or cellular damage (Yun et al 2014). Urea and creatinine concentrations in the sera of mice were used to determine the renal function and show its integrity (Thumamo-Pokam et al 2018). Collected blood samples from vaccinated animals on different days after FMD vaccination until $7^{\text {th }}$ DPV, recorded that the blood urea nitrogen levels, AST and ALT activities were higher than those of the control group (Cha et al 2017). Data presented in Fig 2 reveal the urea and creatinine levels in calves vaccinated with inactivated FMD vaccine. The urea levels increased significantly after vaccination from the $2^{\text {nd }}$ week until the $10^{\text {th }} \mathrm{WPV}$ compared to the control in both groups vaccinated with (ISA 206) and (ISA 206+CLINP). However, this increase of urea levels was at the normal range. Also Fig 2 Showed a high increase in creatinine concentration at the $2^{\text {nd }}$ WPV which is considered above normal level and started to decrease gradually till $10^{\text {th }}$ WPV in only (ISA 206) group compared to other groups. While the calves vaccinated with inactivated FMD vaccine (ISA 206+CLINP) showed a slight increase in creatinine levels at the $2^{\text {nd }} \mathrm{WPV}$ and quickly returned to the normal range at $3^{\text {rd }} \mathrm{WPV}$. In this respect, clinoptilolite is a good material in an adjuvant to the standard therapy because clinoptilolite has material properties which more affinity toward ammonium that is the end-products of protein fermentation (Yao et al 2016).

Table 1. A statistically significant of the means of serum neutralizing test (SNT) in three groups at week post-vaccination for all serotypes of $\mathrm{FMD}^{1}$

\begin{tabular}{|c|c|c|c|c|c|c|c|c|c|}
\hline \multirow{2}{*}{ Groups } & \multicolumn{3}{|c|}{ ISA $206^{2}$} & \multicolumn{3}{|c|}{ ISA206+CLINP $^{3}$} & \multicolumn{3}{|c|}{ CLINP $^{4}$} \\
\hline & Start & peak & end & Start & peak & end & Start & peak & end \\
\hline $\begin{array}{c}\text { Week Post } \\
\text { Vaccination }\end{array}$ & 2 & 12 & 34 & 1 & 12 & 38 & 1 & 10 & 26 \\
\hline Serotype O & $1.55 \pm 0.09^{b}$ & $2.97 \pm 0.03^{c}$ & $1.55 \pm 0.09^{c}$ & $1.70 \pm 0.09^{c}$ & $3.1 \pm 0.03^{c}$ & $1.55 \pm 0.09^{c}$ & $1.55 \pm 0.09^{c}$ & $2.6 \pm 0.09^{b}$ & $1.55 \pm 0.09^{b}$ \\
\hline $\begin{array}{l}\text { Weak Post } \\
\text { Vaccination }\end{array}$ & 2 & 12 & 34 & 1 & 12 & 38 & 1 & 10 & 26 \\
\hline Serotype A & $1.55 \pm 0.09^{b}$ & $3.05 \pm 0.03^{\mathrm{c}}$ & $1.55 \pm 0.09^{\mathrm{c}}$ & $1.75 \pm 0.09^{\mathrm{b}}$ & $3.25 \pm 0.09^{c}$ & $1.60 \pm 0.09^{c}$ & $1.6 \pm 0.09^{\mathrm{b}}$ & $2.9 \pm 0.09^{\mathrm{b}}$ & $1.55 \pm 0.09^{\mathrm{b}}$ \\
\hline $\begin{array}{l}\text { Week Post } \\
\text { Vaccination }\end{array}$ & 2 & 12 & 32 & 1 & 12 & 38 & 1 & 10 & 26 \\
\hline $\begin{array}{l}\text { Serotype } \\
\text { SAT2 }\end{array}$ & $1.55 \pm 0.09^{\mathrm{b}}$ & $3.05 \pm 0.09^{c}$ & $1.6 \pm 0.09^{c}$ & $1.75 \pm 0.09^{b}$ & $3.25 \pm 0.09^{c}$ & $1.65 \pm 0.15^{c}$ & $1.55 \pm 0.09^{b}$ & $2.9 \pm 0.09^{\mathrm{b}}$ & $1.5 \pm 0.09^{\mathrm{b}}$ \\
\hline
\end{tabular}

1 Values with different small letters within a row are significantly different $(\mathrm{P}<0.05)$.

2 ISA 206: calves vaccinated with inactivated FMD vaccine with Montanide ISA 206.

3 ISA 206+CLINP: calves vaccinated with inactivated FMD vaccine with 50\% of Montanide ISA 206 with $1 \mu \mathrm{g} /$ dose clinoptilolite

4 CLINP: calves vaccinated with inactivated FMD vaccine with $1 \mu \mathrm{g} / \mathrm{dose}$ clinoptilolite 
Arab Univ J Agric Sci (2021) 29 (3) 823-832

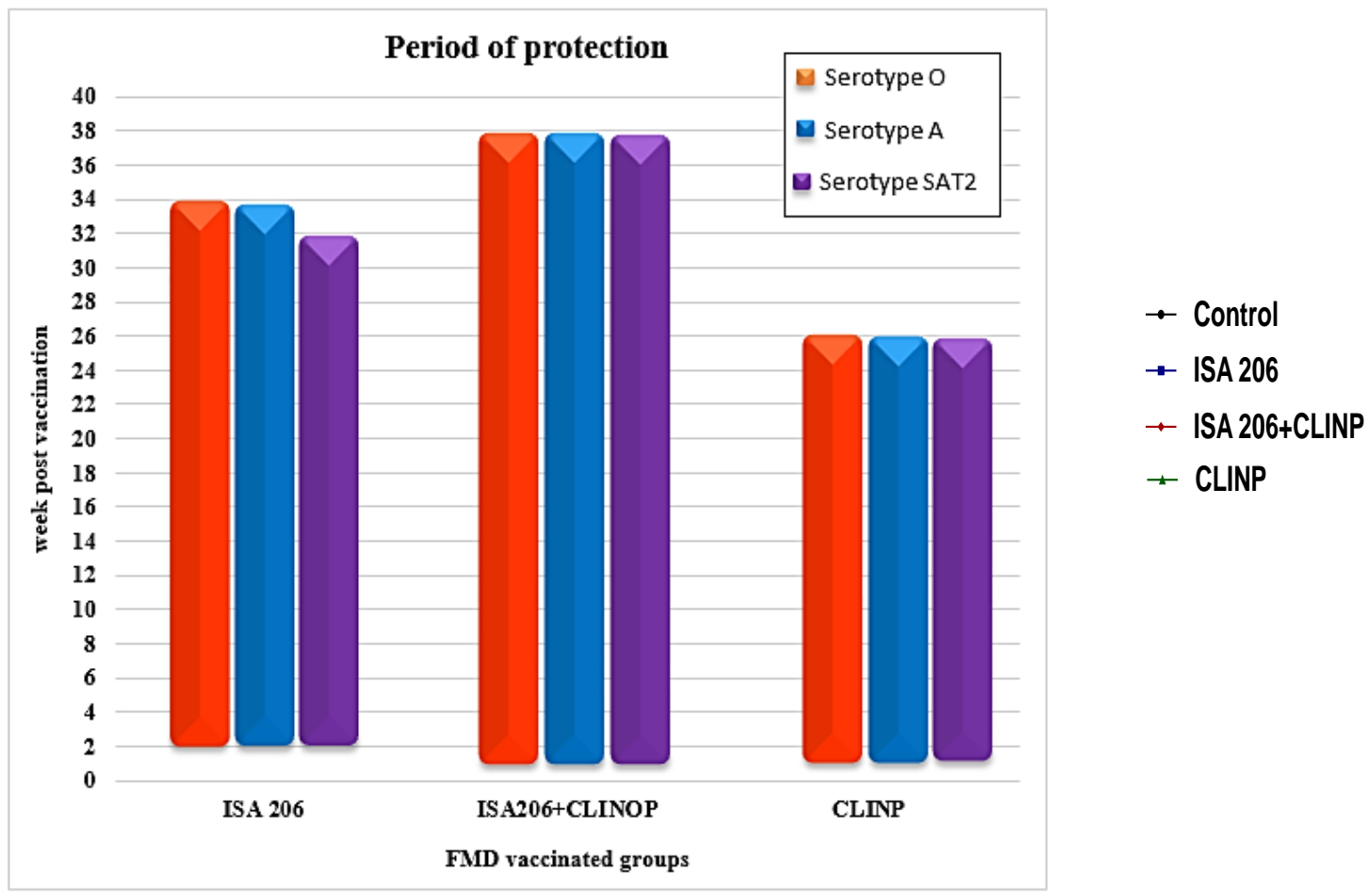

Fig 1. Period of protection in vaccinated calves with different adjuvants of inactivated FMD vaccines during 40 week after vaccination. ISA 206: calves vaccinated with Montanide ISA 206 inactivated FMD vaccine, ISA 206+CLINP: calves vaccinated with 50\% of amount of Montanide ISA $206+1 \mu \mathrm{g}$ /dose clinoptilolite inactivated FMD vaccine, CLINP: calves vaccinated with $1 \mu \mathrm{g} /$ dose clinoptilolite inactivated FMD vaccine.
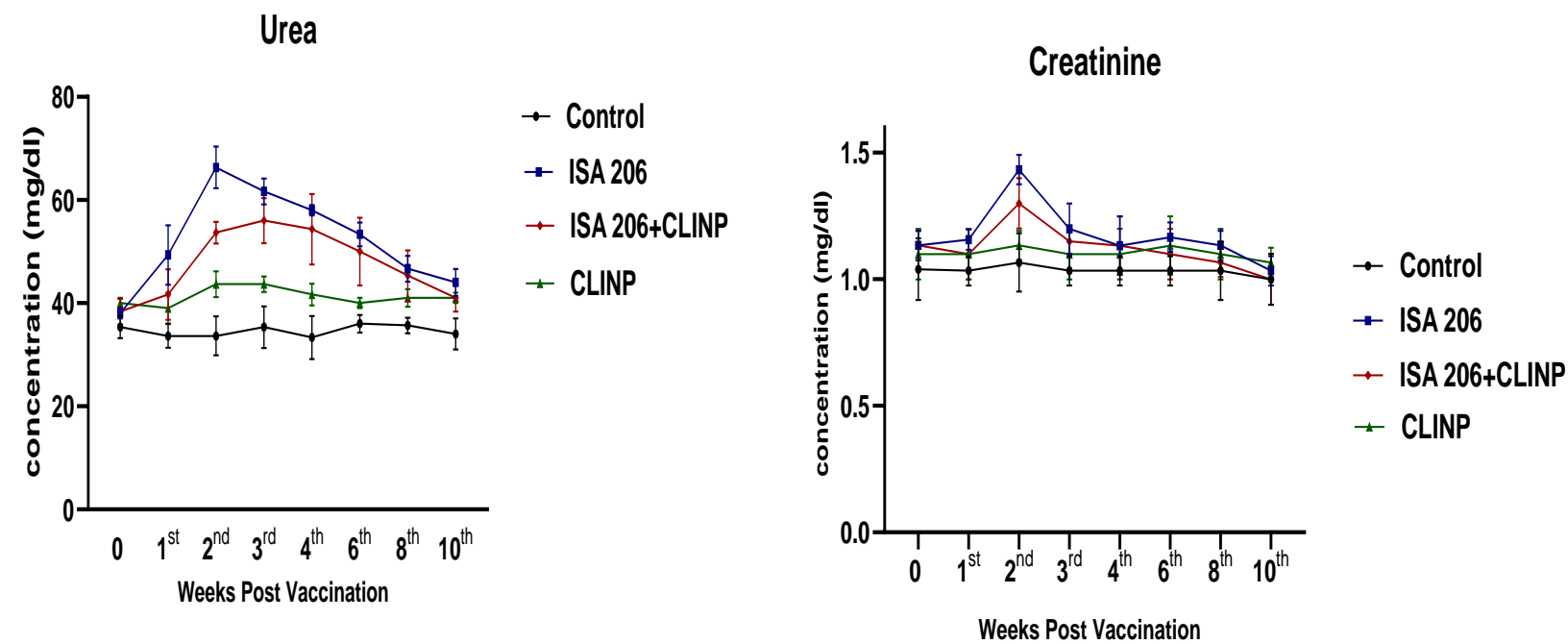

Fig 2. Urea and creatinine concentrations in vaccinated calves with different adjuvants of inactivated FMD vaccines started by time zero till $10^{\text {th }}$ weeks post vaccination. Data are shown as means \pm SD. ISA 206: calves vaccinated with Montanide ISA 206 inactivated FMD vaccine, ISA 206+CLINP: calves vaccinated with 50\% of Montanide ISA 206 with $1 \mu \mathrm{g} /$ dose clinoptilolite inactivated FMD vaccine, CLINP: calves vaccinated with $1 \mu \mathrm{g} /$ dose clinoptilolite inactivated FMD vaccine 
Fig 3 shows the activities of AST and ALT enzymes in blood serum of calves in different groups. The obtained data revealed no significant changes in ALT in all groups. But AST significantly increased with only inactivated FMD vaccine with (ISA 206). In calves, some farm operations caused many stress conditions such as vaccination, and transportation. This stress leads to increase cortisol (stress hormone) concentrations in blood and modulation of inflammatory cytokines (Kim et al 2011).

In addition, this increase in serum AST and urea may be related to glucocorticoid raise so stress can elicit an apparent increase in serum AST and urea concentration (Shawky et al 2016). The increase of AST activity after vaccination as shown in Fig 3 indicated that the vaccination may induce damage effects to liver cells. Nath et al (2014) observed that the calves conjugated with the FMD vaccine had greater AST activity compared to the control group suggesting that the effects of the FMD vaccine caused liver damage. This can be attributed to the oxidative stress of vaccination. This oxidative stress causes liver damage leading to increase of released enzymes from liver cells into the blood (Kanchana and Jeyanthi 2010). Clinoptilolite showed positive effects on hepatocytes which leads to a decrease in the level of malondialdehyde, a marker of oxidative stress, in the liver tissue (Saribeyoglu et al 2011).

Furthermore, results showed in Fig 4 Indicate that the levels of total protein, albumin, globulins concentrations and $\mathrm{A} / \mathrm{G}$ ratio in all calves vaccinated with inactivated FMD vaccine. The three vaccinated groups were significantly higher in total protein and globulins concentrations after vaccination from the $1^{\text {st }}$ WPV until the $10^{\text {th }}$ WPV than those in control. But the group vaccinated with inactivated FMD vaccine with (ISA 206+CLINP) was the highest after vaccination. Conversely, no significant differences in the levels of serum albumin were observed among vaccinated groups compared with control during this period. In this respect, the significant increase of total proteins in the vaccinated groups may be due to the production of antibodies after vaccination. Our results were confirmed with those obtained by Çiftci et al (2019).
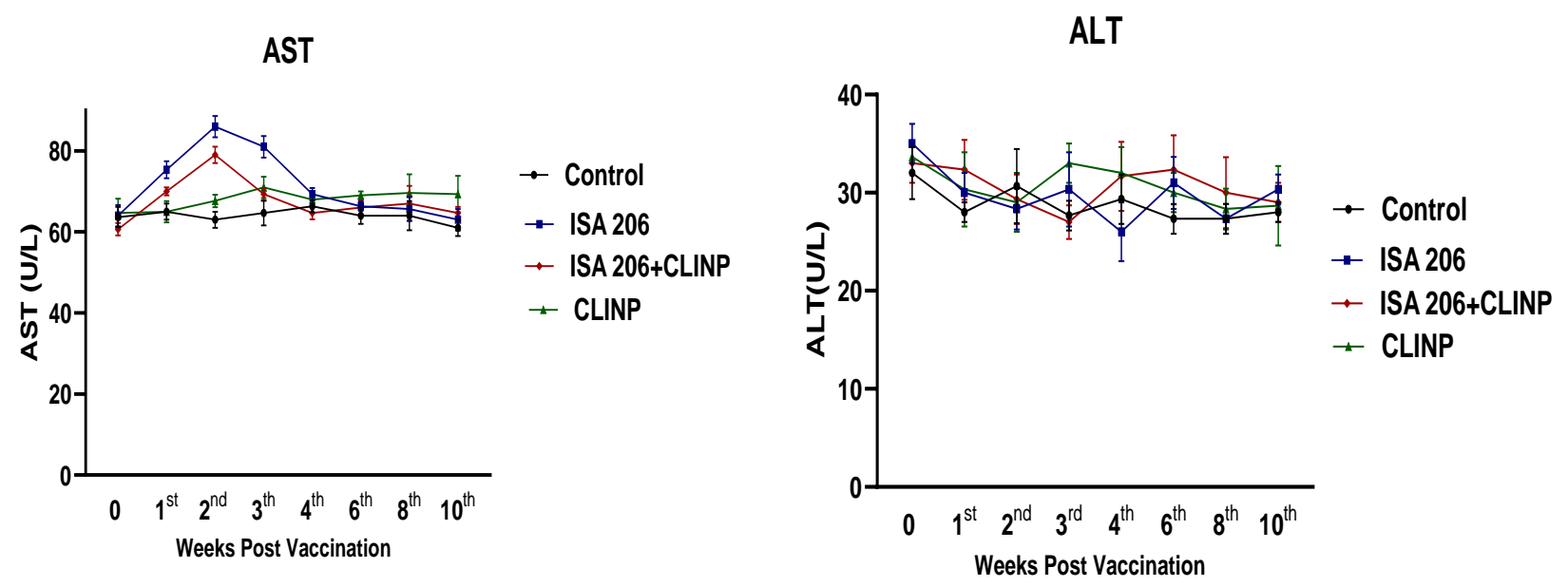

Fig 3. Liver function tests in vaccinated calves with different adjuvants of inactivated FMD vaccines before vaccination till $10^{\text {th }}$ weeks post vaccination. Data are expressed as means \pm SD and the significance. ALT: alanine amino transferase, AST: aspartate amino transferase. ISA 206: calves vaccinated with Montanide ISA 206 inactivated FMD vaccine, ISA 206+CLINP: calves vaccinated with $50 \%$ of Montanide ISA 206 with $1 \mu \mathrm{g} /$ dose clinoptilolite inactivated FMD vaccine, CLINP: calves vaccinated with $1 \mu \mathrm{g} /$ dose clinoptilolite inactivated FMD vaccine 
Arab Univ J Agric Sci (2021) 29 (3) 823-832

Total protein

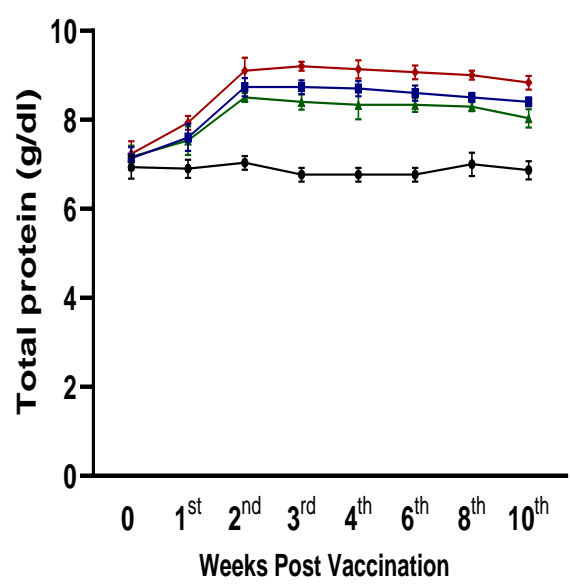

Globulin

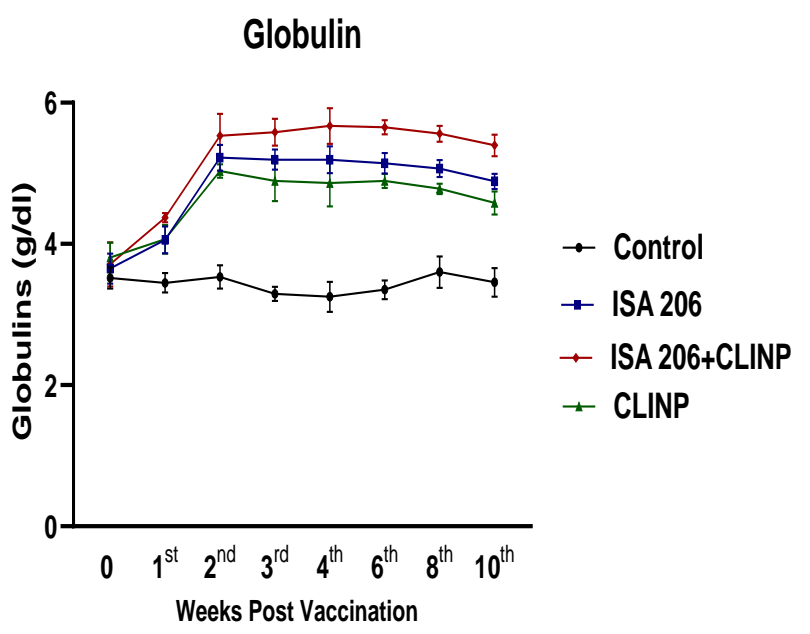

Albumin

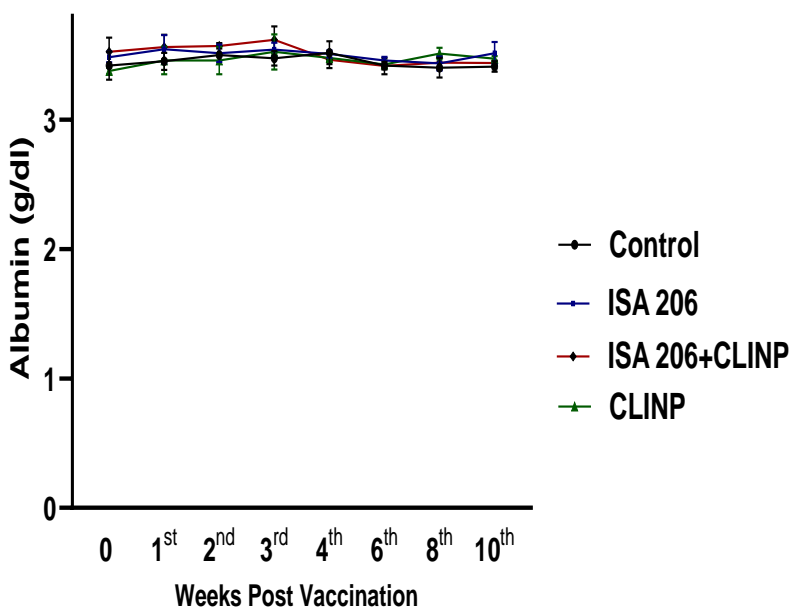

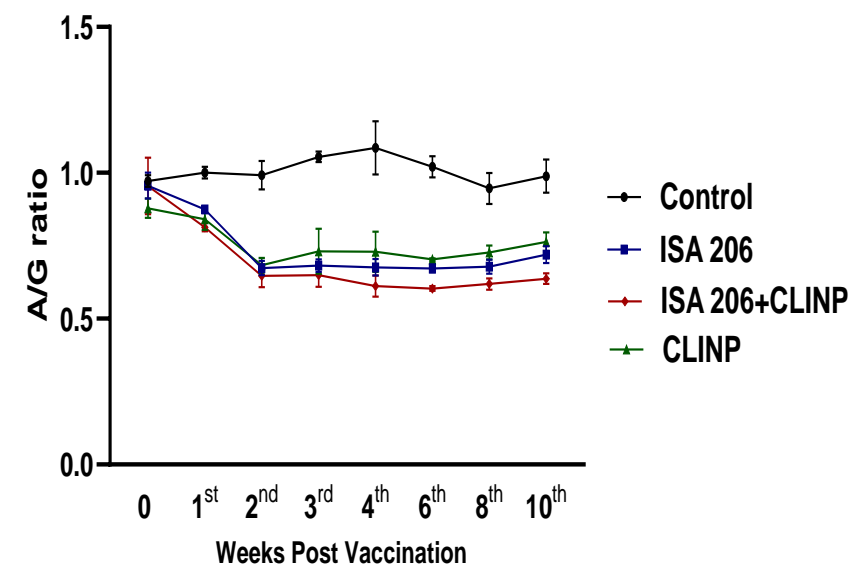

Fig 4. Total proteins, albumin, globulins, and albumin/globulin ratio (A/G) in vaccinated calves with different adjuvants of inactivated FMD vaccines before vaccination until $10^{\text {th }}$ weeks post vaccination. Data are expressed as means \pm SD and the significance. ISA 206: calves vaccinated with Montanide ISA 206 inactivated FMD vaccine, ISA 206+CLINP: calves vaccinated with $50 \%$ of Montanide ISA 206 with $1 \mu \mathrm{g} /$ dose clinoptilolite inactivated FMD vaccine, CLINP: calves vaccinated with $1 \mu \mathrm{g} /$ dose clinoptilolite inactivated FMD vaccine

In the present study also, serum globulin levels increased significantly while $\mathrm{A} / \mathrm{G}$ ratios decreased in all vaccinated groups compared to the control. Specifically, (ISA 206+CLINP) vaccinated calves showed significantly the highest levels of globulin and the lowest ratio of $\mathrm{A} / \mathrm{G}$ compared to other vaccinated groups. These results reflected that the vaccination against FMDV with clinoptilolite can stimulate the humoral immune response in vaccinated calves and increase the antibody production. These results were agreed with those of Park (2013). It is generally accepted that the addition of clinoptilolite at the (ISA 206+CLINP) vaccinated group formulation induced an increase in antibody level and the concentration of serum immunoglobulins in comparison with the other vaccinated groups (Rigden et al 2003). Our results were in conformity with Koch et al (1980) who demonstrated that the enhancement effect of vaccination to globulin concentration in serum when oral or parenteral immunization has been attributed to the reaction of the immune-globulin producing system to the redaction of tissue proteins or antigens. Also, our results concerning globulins concentration were in agreement with previous studies obtained by Stojić et al (2020) who indicate that the clinoptilolite-based mineral adsorbed in the colostrum led to an increasingly significant $\mathrm{IgG}$ concentration in the serum of calves. Our hypothesis is that the addition of clinoptilolite into vaccine formulations as an adjuvant could generate immune response and gives more protection. 


\section{Conclusion}

Using of clinoptilolite as an adjuvant with Montanide ISA 206 oil in FMD trivalent vaccine induce long-lasting immunity more than the oil adjuvant alone or with clinoptilolite alone and improve humoral immunity. Furthermore, it is not toxic, and improving organ functions resulting from the stress of vaccine. So, it is recommended to use the FMD inactivated vaccine adjuvant with oil and clinoptilolite in the companying of vaccination to control FMD. We also recommended increasing the studies of the effect of clinoptilolite as an antioxidant in veterinary.

\section{Acknowledgement}

Our study was supported by the Veterinary Serum and Vaccine Research Institute. (VSVRI), Abbasia, Agriculture research center (ARC), Cairo, Egypt.

\section{References}

Abubakar A, Haque M (2020) Preparation of medicinal plants: Basic extraction and fractionation procedures for experimental purposes. Journal of Pharmacy and Bioallied Sciences 12, 1-10.

https://doi.org/10.4103/jpbs.JPBS_175_19

Ajayi-Oyetunde OO, Bradley CA (2018) Rhizoctonia solani: taxonomy, population biology and management of Rhizoctonia seedling disease of soybean. Plant Pathology 67, 3-17.

https://doi.org/10.1111/ppa.12733

Alaña A, Gabilondo A, Hernando F, Moragues MD, Dominguez JB, Llama MJ, Serra JL (1989) Pectin Lyase Production by a Penicillium italicum Strain. Applied and Environmental Microbiology 55, 1612-1616.

https://doi.org/10.1128/aem.55.6.1612-1616.1989

Bailey MJ, Biely P, Poutanen K (1992) Interlaboratory testing of methods for assay of xylanase activity. Journal of Biotechnology 23 (3), 257-270.

https://doi.org/10.1016/0168-1656(92)90074

Barilli E, Cimmino A, Masi M, Evidente M, Rubiales D, Evidente A (2017) Inhibition of early development stages of rust fungi by the two fungal metabolites cyclopaldic acid and epi epoformin. Pest Management Science 73, 11611168. https://doi.org/10.1002/ps.4438
Edris AE, Kalemba D, Adamiec J, Piątkowski M (2016) Microencapsulation of Nigella sativa oleoresin by spray drying for food and nutraceutical applications. Food Chemistry 204, 326-333.

https://doi.org/10.1016/j.foodchem.2016.02.143

El-Abyad MS, Abu-Taleb AM, Khalil MS (1992) Impact of salinity stress on soil-borne fungi of sugarbeet. Plant and Soil 143, 75-83.

https://doi.org/10.1007/BF00009131

Elwakil MA, El-Refai IM, Awadallah OA, El-Metwall MA, Mohammed MS (2009) Seed-Borne Pathogens of Faba Bean in Egypt: Detection and Pathogencity. Plant Pathology 8, 90-97.

https://doi.org/10.3923/ppj.2009.90.97

Enomoto H, Takahashi S, Takeda S, Hatta H (2020) Distribution of Flavan-3-ol Species in Ripe Strawberry Fruit Revealed by Matrix-Assisted Laser Desorption/Ionization-Mass Spectrometry Imaging. Molecules 25, 103.

https://doi.org/10.3390/molecules25010103

Gawade DB, Perane RR, Suryawanshi AP, Deokar, CD (2017) Extracellular enzymes activity determining the virulence of Rhizoctonia bataticola, causing root rot in soybean. Physiological and Molecular Plant Pathology 100, 49-56.

https://doi.org/10.1016/j.pmpp.2017.06.003

Gvozdeva EL, Volotskaya AV, Sof'in AV, Kudryavtseva NN, Revina TA, Valueva TA (2006) Interaction of proteinases secreted by the fungal plant pathogen Rhizoctonia solani with natural proteinase inhibitors produced by plants. Applied Biochemistry and Microbiology 42, 502-507.

https://doi.org/10.1134/S0003683806050103

Hamza A, Mohamed A, Derbalah A (2016) Unconventional alternatives for control of tomato root rot caused by Rhizoctonia solani under greenhouse conditions. Journal of Plant Protection Research 56, 298-305. https://doi.org/10.1515/jppr-2016-0046

Helmy MM, Gado E, El-Deeb S, Mostafa HM (2015) Phenotypic Diversity and Molecular Identification of the Most Prevalent Anastomosis Group of Rhizoctonia solani Isolated from Diseased Faba Bean Plants. American Journal of Life Sciences 3, 47. https://doi.org/10.11648/j.ajls.20150301.19

Kramer JKG, Fellner V, Dugan MER, Sauer FD, Mossoba MM, Yurawecz MP (1997) Evaluating acid and base catalysts in the methylation of milk and rumen fatty acids with special emphasis on conjugated dienes and total trans fatty acids. Lipids 32, 12191228. https://doi.org/10.1007/s11745-997-0156-3 
Lee J-E, Seo S-M, Huh M-J, Lee S-C, Park I-K (2020) Reactive oxygen species mediatedantifungal activity of cinnamon bark (Cinnamomum verum) and lemongrass (Cymbopogon citratus) essential oils and their constituents against two phytopathogenic fungi. Pesticide Biochemistry and Physiology 168, 104644.

https://doi.org/10.1016/j.pestbp.2020.104644

Liu S, Ruan W, Li J, Xu H, Wang J, Gao Y, Wang J (2008) Biological Control of Phytopathogenic Fungi by Fatty Acids. Mycopathologia 166, 93102. https://doi.org/10.1007/s11046-008-9124-1

Macmillan JD, Vaughn RH (1964) Purification and Properties of a Polygalacturonic Acid-transeliminase Produced by Clostridium multifermentans. Biochemistry 3, 564-572. https://doi.org/10.1021/bi00892a016

Matloob AAAH, Kareem FH, Al-Baldawy MSM (2021) Efficiency of biological control agents and plant extracts against Rhizoctonia solani kuhn causing of damping off in cotton. Indian Journal of Ecology 48, 203-207.

https://doi.org/10.1088/1755-1315/735/1/012079

Mayans O, Scott M, Connerton I, Gravesen T, Benen J, Visser J, Pickersgill R, Jenkins J (1997) Two crystal structures of pectin lyase A from Aspergillus reveal a $\mathrm{pH}$ driven conformational change and striking divergence in the substratebinding clefts of pectin and pectate lyases. Structure 5, 677-689.

https://doi.org/10.1016/S0969-2126(97)00222-0

Menon T, Umamaheswari K, Kumarasamy N, Solomon S, Thyagarajan S (2001) Efficacy of fluconazole and itraconazole in the treatment of oral candidiasis in HIV patients. Acta Tropica 80, 151-154.

https://doi.org/10.1016/S0001-706X(01)00170-X

Marei GIK-h, Abdelgaleil SMA (2017) Antifungal potential and biochemical effects of monoterpenes and phenylpropenes. Plant Protection Science 54, 9-16.

https://doi.org/10.17221/9/2017-PPS
Morris GM, Goodsell DS, Halliday RS, Huey R, Hart WE, Belew RK, Olson AJ (1998) Automated docking using a Lamarckian genetic algorithm and an empirical binding free energy function. Journal of Computational Chemistry 19, 1639-1662.

https://doi.org/10.1002/(SICI)1096987X(19981115)19:14<1639::AID-JCC10>3.0.CO;2B

Morris GM, Huey R, Lindstrom W, Sanner MF, Belew RK, Goodsell DS, Olson AJ (2009) AutoDock4 and AutoDockTools4: Automated docking with selective receptor flexibility. Journal of Computational Chemistry 30, 2785-2791. https://doi.org/10.1002/jcc.21256

Nguyen V-N, Nguyen D-M-C, Seo D-J, Park R-D, Jung W-J (2009) Antimycotic activities of Cinnamonderived compounds against Rhizoctonia solani in vitro. BioControl 54, 697-707.

https://doi.org/10.1007/s10526-009-9220-2

Numpaque MA, Oviedo LA, Gil JH, García CM, Durango DL (2011) Thymol and carvacrol: biotransformation and antifungal activity against the plant pathogenic fungi Colletotrichum acutatum and Botryodiplodia theobromae. Tropical Plant Pathology 36, 3-13.

https://doi.org/10.1590/S1982-56762011000100001

Ogoshi A (1996) Introduction - The Genus Rhizoctonia, in: Sneh B., Jabaji-Hare S., Neate SM., Dijst G (Eds). Rhizoctonia Species: Taxonomy, Molecular Biology, Ecology, Pathology and Disease Control. Springer science \& business media, Dordrecht, Netherlands, pp. 1-9.

https://doi.org/10.1007/978-94-017-2901-7_1

Pan X, Tan N, Zeng G, Zhang Y, Jia R (2005) Amentoflavone and its derivatives as novel natural inhibitors of human Cathepsin B. Bioorganic \& Medicinal Chemistry 13, 5819-5825.

https://doi.org/10.1016/j.bmc.2005.05.071

Perombelon M, Hadly G (1965) Production of pectic enzymes by pathogenic and symbiotic Rhizoctinia strains. New Phytologist 64, 144-151.

https://doi.org/10.1111/j.1469-8137.1965.tb05382.x

Tsugawa H, Nakabayashi R, Mori T, Yamada Y, Takahashi M, Rai A, Sugiyama R, Yamamoto H, Nakaya T, Yamazaki M, Kooke R, Bac-Molenaar JA, Oztolan-Erol N, Keurentjes JJB, Arita M, Saito K (2019) A cheminformatics approach to characterize metabolomes in stable-isotope-labeled organisms. Nature methods 16, 295-298.

https://doi.org/10.1038/s41592-019-0358-2 
Arab Univ J Agric Sci (2021) 29 (3) 823-832

Rathmell WG (1984) The discovery of new methods of chemical disease control: current developments, future prospects and the role of biochemical and physiological research. Advances in Plant Pathology 2, 259-288.

Reyes F, Martinez MJ, Lahoz R, Archer SR (1984) Characterization as glycerol of an inhibitor of pectin lyases from autolysing cultures of Botrytis cinerea. Transactions of the British Mycological Society 82, 689-696.

https://doi.org/10.1016/S0007-1536(84)80109-6

Russell JB, Diez-Gonzalez F (1997) The Effects of Fermentation Acids on Bacterial Growth, in: Advances in Microbial Physiology. 39, 205-234. https://doi.org/10.1016/S0065-2911(08)60017-X

Rypniewski WR, Dambmann C, von der Osten C, Dauter M, Wilson KS (1995) Structure of inhibited trypsin from Fusarium oxysporum at $1.55 \AA$ A. Acta Crystallographica Section D STRUCTURAL BIOLOGY 51, 73-85.

https://doi.org/10.1107/S0907444994009169

Rypniewski WR, Østergaard PR, NørregaardMadsen M, Dauter M, Wilson KS (2001) Fusarium oxysporum trypsin at atomic resolution at 100 and $283 \mathrm{~K}$ : a study of ligand binding. Acta Crystallographica Section D STRUCTURAL BIOLOGY Crystallogr 57, 8-19. https://doi.org/10.1107/S0907444900014116

Sanner MF (1999) Python: A programming language for software integration and development. Journal of Molecular Graphics and Modelling 17, 57-61. PMID: 10660911.

Shin DH, Bae C, Kim-Han JS, Lee JH, Choi IY, Son KH, Kang SS, Kim W-K, Han BH (2006) Polyphenol amentoflavone affords neuroprotection against neonatal hypoxicischemic brain damage via multiple mechanisms. Journal of Neurochemistry 96, 561-572. https://doi.org/10.1111/j.1471-4159.2005.03582.x

Snedecor GW, Cochran WG (1980) Statistical Methods, $7^{\text {rd }}$ ed, Lowa state university press, Lowa, USA.

Wei L-H, Chen T-R, Fang H-B, Jin Q, Zhang S-J, Hou J, Yu Y, Dou T-Y, Cao Y-F, Guo W-Z, Ge G-B (2019) Natural constituents of St. John's Wort inhibit the proteolytic activity of human thrombin. International Journal of Biological Macromolecules 134, 622-630.

https://doi.org/10.1016/j.ijbiomac.2019.04.181

Xie Y, Huang Q, Wang Z, Cao H, Zhang D (2017) Structure-activity relationships of cinnamaldehyde and eugenol derivatives against plant pathogenic fungi. Industrial Crops and Products 97, 388-394.

https://doi.org/10.1016/j.indcrop.2016.12.043

Yao H, Chen B, Zhang Y, Ou H, Li Y, Li S, Shi P, Lin $X$ (2017) Analysis of the Total Biflavonoids Extract from Selaginella doederleinii by HPLC-QTOF-MS and Its In Vitro and In Vivo Anticancer Effects. Molecules 22(2), 325.

https://doi.org/10.3390/molecules22020325

Zachow C, Grosch R, Berg, G (2011) Impact of biotic and a-biotic parameters on structure and function of microbial communities living on sclerotia of the soilborne pathogenic fungus Rhizoctonia solani. Applied Soil Ecology 48, 193-200.

https://doi.org/10.1016/j.apsoil.2011.03.006

Zhang Y, Fu Y, Zhou S, Kang L, Li C (2013) A straightforward ninhydrin-based method for collagenase activity and inhibitor screening of collagenase using spectrophotometry. Analytical Biochemistry 434, 46-48.

https://doi.org/10.1016/j.ab.2013.02.030 